\title{
Thyroid cancer in a patient with a germline MSH2 mutation. Case report and review of the Lynch syndrome expanding tumour spectrum
}

\author{
Rein P. Stulp', Johanna C. Herkert', Arend Karrenbeld², Bart Mol', Yvonne J. Vos', Rolf H. Sijmons' \\ 'Department of Genetics, University Medical Center Groningen, University of Groningen, Groningen, The Netherlands \\ 2Department of Pathology, University Medical Center Groningen, University of Groningen, Groningen, The Netherlands
}

Key words: Lynch syndrome, mutations, MSH2, thyroid cancer

Corresponding author: Rein P. Stulp, Department of Genetics, University Medical Center Groningen, P0-Box 30.001, 9700 RB Groningen, The Netherlands, phone: +31 5036172 29, fax: +31 5036172 31, e-mail: r.p.stulp@medgen.umeg.nl

Submitted: 8 February 2008

Accepted: 14 February 2008

\begin{abstract}
Lynch syndrome (HNPCC) is a dominantly inherited disorder characterized by germline defects in DNA mismatch repair (MMR) genes and the development of a variety of cancers, predominantly colorectal and endometrial. We present a 44-year-old woman who was shown to carry the truncating MSH2 gene mutation that had previously been identified in her family. Recently, she had been diagnosed with an undifferentiated carcinoma of the thyroid and an adenoma of her coecum. Although the thyroid carcinoma was not MSI-high (1 out of 5 microsatellites instable), it did show complete loss of immunohistochemical expression for the MSH2 protein, suggesting that this tumour was not coincidental. Although the risks for some tumour types, including breast cancer, soft tissue sarcoma and prostate cancer, are not significantly increased in Lynch syndrome, MMR deficiency in the presence of a corresponding germline defect has been demonstrated in incidental cases of a growing range of tumour types, which is reviewed in this paper. Interestingly, the MSH2-associated tumour spectrum appears to be wider than that of $\mathrm{MLH1}$ and generally the risk for most extra-colonic cancers appears to be higher for MSH2 than for MLH1 mutation carriers. Together with a previously reported case, our findings show that anaplastic thyroid carcinoma can develop in the setting of Lynch syndrome. Uncommon Lynch syndrome-associated tumour types might be useful in the genetic analysis of a Lynch syndrome suspected family if samples from typical Lynch syndrome tumours are unavailable.
\end{abstract}

\section{Introduction}

Lynch syndrome, also known as hereditary nonpolyposis colorectal cancer (HNPCC), is an autosomal dominant disorder associated with a germline mutation in one of the DNA mismatch repair (MMR) genes, most commonly $\mathrm{MLH} 1$ and $\mathrm{MSH} 2$ and less frequently MSH6 and PMS2. Lynch syndrome is characterized by a strongly increased risk of developing colorectal cancer and several extra-colonic malignancies including carcinomas of the endometrium, ovary, ureter, stomach and small intestine. Tumours develop at a relatively young age. Although the risks for some common types of cancer, for example breast cancer [1-3], or rarer tumour types, for example malignant fibrous histiocytoma (MFH) [4], do not appear to be significantly increased in Lynch syndrome, MMR deficiency in the presence of a corresponding germline defect has been demonstrated in incidental cases of these tumours. 
Here we report a 44-year-old woman from a Lynch syndrome, Amsterdam positive family who was referred for DNA testing. She had a recent history of a colorectal adenoma and an undifferentiated carcinoma of her thyroid and was shown to carry the truncating $\mathrm{MSH} 2$ mutation that was known to segregate in her family. Traditionally, thyroid cancer is not considered to be part of the Lynch syndrome tumour spectrum. Our findings, however, suggest that this tumour was not coincidental, but likely developed in association with the underlying germline defect in the $\mathrm{MSH} 2$ gene. We reviewed the literature on unusual manifestations of inherited mismatch repair gene mutations.

\section{Methods}

After genetic counselling, DNA analysis of the MSH2 gene was performed in this 44-year-old woman by extracting DNA from lymphocytes, followed by a PCR amplification of exon 11 of the MSH2 gene. The PCR product was analyzed by denaturing gradient gel electrophoresis (DGGE) and compared with DNA from a family member carrying the mutation [5].

Immunohistochemical staining for MLH1, PMS2, MSH2 and MSH6 protein expression was performed on formalin-fixed, paraffin-embedded sections of tumour as described previously [6].

DNA was extracted from both tumour and normal tissue. Microsatellite instability analysis was performed on formalin-fixed, paraffin-embedded sections of tumour and corresponding normal tissue. Following DNA amplification using fluorescent labelled primers, a panel of five microsatellites recommended by the $\mathrm{NCl}$ [7] and consisting of BAT25, BAT26, D2S123, D5S346 and D17S250 was analyzed for allelic shift. The amplified PCR products were analyzed on an $A B I$ Genetic Analyzer.

We searched the English literature through Entrez PubMed (www.ncbi.nlm.nih.gov/sites/entrez) using sets of keywords to identify publications on tumours reported in patients with germline mismatch repair gene mutations. The reference lists of publications found through this approach were searched for additional relevant papers.

\section{Results}

Genetic analysis of the MSH2 gene in the patient revealed the c.1704_1705delAG mutation, already known to segregate in her family. Her undifferentiated thyroid carcinoma showed complete loss of immunohistochemical expression of the MSH2 and MSH6 protein in the presence of normal positive internal controls, and no loss of the MLH1 and PMS2 protein. Of the five microsatellite markers tested, BAT26 showed instability. Therefore the thyroid tumour was classified as MSI-low.

The acknowledged Lynch syndrome tumour spectrum is shown in Table 1. The cumulative risks and

Table 1. Lynch syndrome tumour spectrum. Cumulative risks and average ages at diagnosis

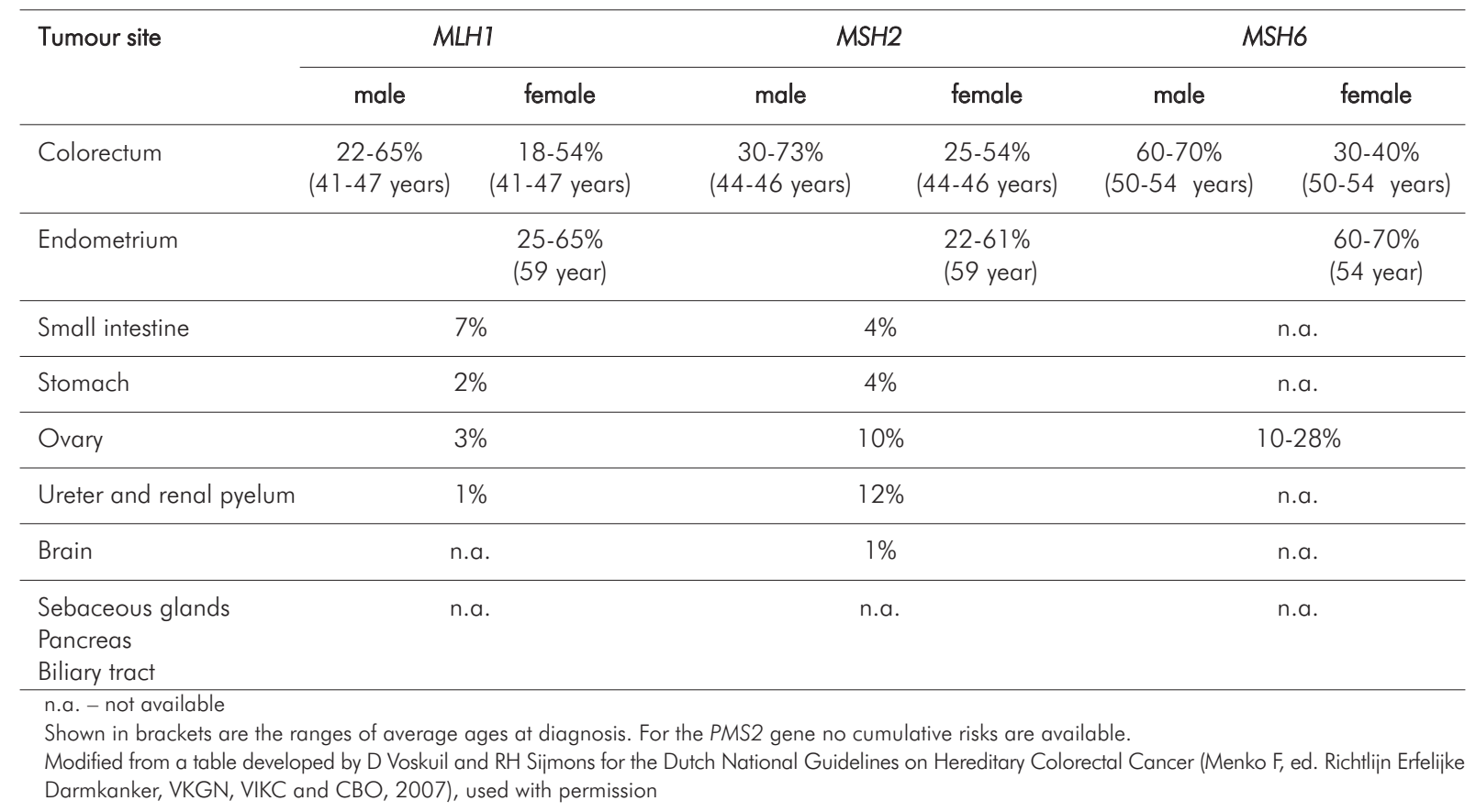


average ages of diagnosis shown in this table were retrieved from papers reporting these data in proven mutation carriers [8-17], rather than from papers that had included untested patients and/or first-degree relatives in their analyses. The reports on 'unusual' tumours in Lynch syndrome patients are presented in Table 2. For comparison, we list the tumour spectrum associated with bi-allelic MMR gene germline mutations in Table 3.

\section{Discussion}

Undifferentiated thyroid carcinoma is not commonly associated with Lynch syndrome. In our patient the immunohistochemical loss of expression for the MSH2 and MSH6 protein suggested that this tumour was not coincidental, but due to the underlying mutation in the MSH2 gene. Loss of MSH6 expression in tumours is often observed in case of germline MSH2 mutations and can be explained by loss of its stabilizing partner MSH2. Broaddus et al. [18] contended that for both an adrenal and a thyroid carcinoma an $\mathrm{MSH} 2$ gene mutation was causally linked because the tumour showed loss of MSH2 protein with immunohistochemical staining, but retained expression of $M L H 1$. This staining pattern was similar to that seen in the more common Lynch syndrome related malignancies in these families. Although both adrenal and thyroid carcinoma showed loss of MSH2 immunohistochemical expression, neither tumour was microsatellite instable (MSI-high). Loss of protein expression in the absence of MSI has been observed before in Lynch syndrome, most notably in patients with MSH6 mutations [6, 19].

In the past, the Lynch syndrome tumour spectrum has primarily been defined through an epidemiological and statistical approach. From a clinical point of view this approach is of course still very valid as many clinicians will be primarily interested in tumours that

Table 2. Unusual tumours in patients with Lynch syndrome

\begin{tabular}{|c|c|c|c|c|c|c|c|c|}
\hline Tumour type & Age & Gene & Mutation & MSI & $\begin{array}{c}\text { IHC } \\
\text { MLHI }\end{array}$ & $\begin{array}{c}\text { IHC } \\
\text { MSH2 }\end{array}$ & $\begin{array}{c}\text { IHC } \\
\text { MSH6 }\end{array}$ & Ref. \\
\hline Non-Hodgkin's lymphoma & 48 & $\mathrm{MSH} 2$ & large rearrangement & high & + & - & - & 45 \\
\hline Rhabdomyosarcoma, pleomorphic & 34 & MSH2 & not published & high & + & - & ND & 46 \\
\hline Breast carcinoma, ductal & 49 & $\mathrm{MSH} 2$ & c. $1705-1706$ del GA & high & + & - & - & 3 \\
\hline Fibrous histiocytoma, malignant & 45 & MSH2 & p.G429X & high & + & - & ND & 4 \\
\hline Adrenal cortical carcinoma & 34 & $\mathrm{MSH} 2$ & c.IVS10+1G>A & low & + & - & ND & 18 \\
\hline Thyroid carcinoma, anaplastic & 39 & MSH2 & p.Q824X & low & + & - & ND & 18 \\
\hline Thyroid carcinoma, undifferentiated & 44 & MSH2 & c.1704_1705 del AG & low & + & - & - & c \\
\hline Pancreatic medullary carcinoma & 63 & MSH2 & c.C1147T p.R383X & high & + & - & - & 47 \\
\hline Prostate adenocarcinoma & 61 & $\mathrm{MSH} 2$ & c.del exon 5 & high & + & - & - & 48 \\
\hline Liposarcoma & 40 & $\mathrm{MSH} 2$ & c.del AT codon 677 & ND & + & - & ND & 49 \\
\hline Hepatic cholangiocarcinoma, mucinous & 41 & MSH2 & c.T2026C & high & + & - & - & 50 \\
\hline Uterine carcinosarcoma & 46 & MLHT & c.G1896C p.E632D & ND & - & + & ND & 51 \\
\hline Renal cell carcinoma, clear cellA & 51 & MLHT & c.C1528T & high & - & ND & ND & 1 \\
\hline Breast carcinoma ${ }^{A}$, ductal & 34 & MLHI & c.C1528T & high & - & ND & ND & 1 \\
\hline Breast carcinoma, male ductal & 71 & MLHI & 4 bp dup in codon $755-756$ & high & $N D^{B}$ & ND & ND & 52 \\
\hline Breast carcinoma, male & 46 & MLHT & c.2215-2218 dup AAAC & high & $N D^{B}$ & ND & ND & 2 \\
\hline
\end{tabular}

ND - not determined, IHC - results from immunohistochemical staining of the tumour for the protein coded by that gene, MSI - classification of the tumour microsatellite instability test results

$A_{\text {in this }}$ South-African family 5 breast cancer patients and a relative with renal cell cancer all carried the same mutation and showed microsatellite instability and loss of $\mathrm{MLH} 1$ protein in their tumours

$B$ in this tumour loss of heterozygosity for MLHI was detected

cpatient reported in this paper 
Table 3. Tumours observed in patients with bi-allelic MMR gene germline mutations

\begin{tabular}{|c|c|c|c|c|}
\hline Tumour type & $\begin{array}{l}\text { MLH1 } \\
\text { mean age (range), } \mathrm{N}\end{array}$ & $\begin{array}{l}\text { MSH2 } \\
\text { mean age (range), } \mathrm{N}\end{array}$ & $\begin{array}{l}\text { MSH6 } \\
\text { mean age (range), } \mathrm{N}\end{array}$ & $\begin{array}{l}\text { PMS2 } \\
\text { mean age (range), } \mathrm{N}\end{array}$ \\
\hline Acute leukaemia & $2,1 / 14$ & & & \\
\hline Acute myeloid leukaemia & $6,1 / 14$ & & $7,1 / 15$ & \\
\hline Atypical chronic myeloid leukaemia & $1,1 / 14$ & & & \\
\hline B-acute lymphatic leukaemia & & & & $10(10), 1 / 43$ \\
\hline $\begin{array}{l}\text { T-acute lymphatic leukaemia/ } \\
\text { T cell leukaemia }\end{array}$ & & $2,1 / 7$ & & $2(2), 1 / 43$ \\
\hline Lymphoblastic lymphoma & & & $5,1 / 15$ & $9(6-15), 3 / 43$ \\
\hline $\mathrm{NHL/T-cell} \mathrm{lymphoma}$ & $3,1 / 14$ & $1.7(1-2), 3 / 7$ & $10,1 / 15$ & $11(3-17), 4 / 43$ \\
\hline Small bowel carcinoma, not specified & & & & $15.5(15-16), 2 / 43$ \\
\hline Adenocarcinoma duodenum & $11,1 / 14$ & & & \\
\hline Breast cancer & $35,1 / 14$ & & & \\
\hline Colorectal cancer & $22(9-35), 3 / 14$ & $11.5(11-12), 2 / 7$ & $16.6(8-31), 5 / 15$ & $15.9(11-24), 10 / 43$ \\
\hline Endometrial cancer & & & $24,1 / 15$ & $23.5(23-24), 2 / 43$ \\
\hline Brain tumour, not specified & & & & $24(24), 1 / 43$ \\
\hline Glioma & $4,1 / 14$ & & & $15(15), 1 / 43$ \\
\hline Astrocytoma/glioblastoma (multiforme) & $4,1 / 14$ & $3,1 / 7$ & $8(7-9), 3 / 15$ & $7.1(2-17), 8 / 43$ \\
\hline Glioblastoma of the spinal cord & & & $2,1 / 15$ & \\
\hline Oligodendroglioma & & & $10,1 / 15$ & 16.5 (14-19), 2/43 \\
\hline Infantile myofibromatosis & & & & $1(1), 1 / 43$ \\
\hline Medulloblastoma & $7,1 / 14$ & & $7,1 / 15$ & \\
\hline Neuroblastoma & & & & $13(13), 1 / 43$ \\
\hline $\begin{array}{l}\text { Primitive neuroectodermal tumour } \\
\text { (PNET) of brain or ovary }\end{array}$ & & & & $11(4-21), 5 / 43$ \\
\hline Sarcoma & $65,1 / 14$ & & & \\
\hline Ureter/renal pelvis carcinoma & & & & $15(15), 1 / 43$ \\
\hline Wilms' tumour & $4,1 / 14$ & & & \\
\hline Total & 14 (11 patients) & 7 (7 patients) & 15 (10 patients) & 43 (28 patients) \\
\hline
\end{tabular}

For each MMR gene and each of the tumours, the mean age at diagnosis is given in years. If more than one tumour was reported for each type then the range of ages at diagnosis is shown between brackets. The number of each of the tumour types observed for a particular MMR gene is shown as number/total of tumours reported for that gene in bi-allelic mutation carriers. Multiple primary tumours were reported frequently and the total number of reported tumours and total number of patients are presented in the last row for each of the genes [20-44]

have a significantly increased risk of developing in their patients. Cumulative cancer risks for Lynch syndrome were usually based on retrospective cohort analysis of families meeting the Amsterdam criteria, often including families without proven mutations and untested firstdegree relatives. More recently studies have focused on proven mutation carriers only. The risk figures listed in Table 1 are based on the latter type of studies [8-17]. Interestingly, the risk for gastric, ovarian, ureter/renal pyelum and brain tumours appears to be higher for carriers of MSH2 mutations than for carriers of MLHT mutations. In addition to the statistical 
approach, the tumour spectrum can be broadened through analysis of tumours occurring in MMR gene mutation carriers. Again, patients with atypical Lynch syndrome tumours as listed in Table 2 more often have been reported to carry an $\mathrm{MSH} 2$ than an $\mathrm{MLH} 1$ mutation. Also a wider range of tumours is observed for MSH2 than for MLH1 in these patients. At this point we can only speculate on the reason for these differences. MLH1 and MSH2 each create a heterodimer with different partners and have different roles in the detection and repair of DNA mismatches. For each of these protein complexes, deficiency might have a different impact on types and quantity of mismatches left unrepaired and the effect deficiency has on different target genes. The absence of MSH6 and PMS2 mutations in Table 2 might simply be caused by the fact that these mutations have been less frequently observed in Lynch syndrome in general. Ascertainment bias, however, cannot be excluded as laboratories did not test MSH6 and PMS2 in their analyses of Lynch syndrome suspected patients until fairly recently. Nevertheless, the absence of MSH6 and PMS2 from the listed reports might also reflect a true difference in associated tumour spectrum.

The tumours listed in Table 2 are not known to develop significantly more frequently in MMR gene mutation carriers than in the general population. Loss of MMR function may or may not have contributed significantly to tumour development in these particular cases. Generally, in these organs loss of the wild type allele in MMR gene mutation carriers and/or subsequently the accumulation of clinically important unrepaired mutations in cancerassociated target genes are apparently relatively rare. It is interesting to look at the types of cancer that develop in patients who have inherited bi-allelic MMR gene mutations (Tabele 3.). These patients are born with a mismatch repair deficiency and can present with tumours that rarely occur in carriers of single allele MMR gene mutations who need to lose their WT allele in their tissues first. Several studies have demonstrated that these bi-allelic mutations can lead to a phenotypically distinct recessive syndrome with predominantly childhood onset brain tumours, leukaemia and lymphoma, bowel tumours and endometrial carcinoma [20-44]. A striking feature of these patients is that nearly all of them display some features, spotty hyperpigmentation of the skin and Lisch nodules of the irides, usually observed in neurofibromatosis type I. Some of the reported tumour types, sarcoma, NHL and early-onset breast cancer match the types incidentally reported in patients with single allele MMR gene mutations, which further supports the notion that these tumour types could be causally linked to inherited MMR gene mutations.
Whether or not MMR deficiency contributed significantly to development of the types of cancer occasionally seen in Lynch syndrome patients remains to be determined. From a practical point of view, we conclude that unusual tumours in Lynch syndrome can show loss of immunohistochemical staining that corresponds to the MMR germline mutation. Therefore these tumours, especially of those types that rarely occur in the general population, could be useful when trying to predict MMR gene mutations in Lynch syndrome suspected families for mutation analysis [6, 19] if the typical Lynch syndrome-associated tumours are unavailable.

\section{References}

1. Blokhuis MM, Goldberg PA, Pietersen GE, Algar U, Vorster AA, Govender D, Ramesar RS. The extracolonic cancer spectrum in females with the common 'South African' hMLH1 c.C1528T mutation. Fam Cancer 2007 November 30.

2. Risinger JI, Barrett JC, Watson P, Lynch HT, Boyd J. Molecular genetic evidence of the occurrence of breast cancer as an integral tumor in patients with the hereditary nonpolyposis colorectal carcinoma syndrome. Cancer 1996; 77: 1836-1843.

3. Westenend PJ, Schutte R, Hoogmans MM, Wagner A, Dinjens WN. Breast cancer in an MSH2 gene mutation carrier. Hum Pathol 2005; 36: 1322-1326.

4. Sijmons R, Hofstra R, Hollema H, Mensink R, van der Hout A, Hoekstra H, Kleibeuker J, Molenaar W, Wijnen J, Fodde R, Vasen $\mathrm{H}$, Buys $\mathrm{C}$. Inclusion of malignant fibrous histiocytoma in the tumour spectrum associated with hereditary non-polyposis colorectal cancer. Genes Chromosomes Cancer 2000; 29: 353-355.

5. Wu Y, Nyström-Lahti M, Osinga J, Looman MW, Peltomäki P, Aaltonen LA, de la Chapelle A, Hofstra RM, Buys CH. MSH2 and $\mathrm{MLH} 1$ mutations in sporadic replication error-positive colorectal carcinoma as assessed by two-dimensional DNA electrophoresis. Genes Chromosomes Cancer 1997; 18: 269-278.

6. Berends MJ, Wu Y, Sijmons RH, Mensink RG, van der Sluis T, Hordijk-Hos JM, de Vries EG, Hollema H, Karrenbeld A, Buys CH, van der Zee AG, Hofstra RM, Kleibeuker JH. Molecular and clinical characteristics of MSH6 variants: an analysis of 25 index carriers of a germline variant. Am J Hum Genet 2002; 70: 26-37.

7. Umar A, Boland CR, Terdiman JP, Syngal S, de la Chapelle A, Rüschoff J, Fishel R, Lindor NM, Burgart $L$, Hamelin R, Hamilton SR, Hiatt RA, Jass J, Lindblom A, Lynch HT, Peltomaki P, Ramsey SD, Rodriguez-Bigas MA, Vasen HF, Hawk ET, Barrett JC, Freedman AN, Srivastava S. Revised Bethesda Guidelines for hereditary nonpolyposis colorectal cancer (Lynch syndrome) and microsatellite instability. J Natl Cancer Inst 2004; 96: 261-268.

8. Aarnio M, Sankila R, Pukkala E, Salovaara R, Aaltonen LA, de la Chapelle A, Peltomäki P, Mecklin JP, Järvinen HJ. Cancer risk in mutation carriers of DNA-mismatch-repair genes. Int J Cancer 1999; 81: 214-8

9. Dunlop MG, Farrington SM, Carothers AD, Wyllie AH, Sharp L, Burn J, Liu B, Kinzler KW, Vogelstein B. Cancer risk associated with germline DNA mismatch repair gene mutations. Hum Mol Genet 1997; 6: 105-110.

10. Hendriks YM, Wagner A, Morreau H, Menko F, Stormorken A, Quehenberger F, Sandkuiil L, Møller P, Genuardi M, Van Houwelingen $H$, Tops $C$, Van Puijenbroek M, Verkuijlen P, Kenter G, Van Mil A, Meijers-Heijboer H, Tan GB, Breuning MH, Fodde R, Wijnen JT, Bröcker-Vriends AH, Vasen H. Cancer risk 
in hereditary nonpolyposis colorectal cancer due to MSH6 mutations: impact on counseling and surveillance. Gastroenterology 2004; 127: 17-25.

11. Plaschke J, Engel C, Krüger S, Holinski-Feder E, Pagenstecher C, Mangold E, Moeslein G, Schulmann K, Gebert J, von Knebel Doeberitz M, Rüschoff J, Loeffler M, Schackert HK. Lower incidence of colorectal cancer and later age of disease onset in 27 families with pathogenic MSH6 germline mutations compared with families with MLH1 or MSH2 mutations: the German Hereditary Nonpolyposis Colorectal Cancer Consortium. J Clin Oncol 2004; 22: 4486-4494.

12. Quehenberger F, Vasen HF, van Houwelingen HC. Risk of colorectal and endometrial cancer for carriers of mutations of the hMLH1 and hMSH2 gene: correction for ascertainment. J Med Genet 2005; 42: 491-496.

13. Vasen HF, Wijnen JT, Menko FH, Kleibeuker JH, Taal BG, Griffioen G, Nagengast FM, Meijers-Heijboer EH, Bertario L, Varesco L, Bisgaard ML, Mohr J, Fodde R, Khan PM. Cancer risk in families with hereditary nonpolyposis colorectal cancer diagnosed by mutation analysis. Gastroenterology 1996; 1 10: 1020-1027.

14. Vasen HF, Stormorken A, Menko FH, Nagengast FM, Kleibeuker JH, Griffioen G, Taal BG, Moller P, Wijnen JT. MSH2 mutation carriers are at higher risk of cancer than MLH1 mutation carriers: a study of hereditary nonpolyposis colorectal cancer families. J Clin Oncol 2001; 19: 4074-4080.

15. Hampel H, Stephens JA, Pukkala E, Sankila R, Aaltonen LA, Mecklin JP, de la Chapelle A. Cancer risk in hereditary nonpolyposis colorectal cancer syndrome: later age of onset. Gastroenterology 2005; 129: 415-421.

16. Carayol J, Khlat M, Maccario J, Bonaiiti-Pellié C. Hereditary nonpolyposis colorectal cancer: current risks of colorectal cancer largely overestimated. J Med Genet 2002; 39: 335-339.

17. Buttin BM, Powell MA, Mutch DG, Babb SA, Huettner PC, Edmonston TB, Herzog TJ, Rader JS, Gibb RK, Whelan AJ, Goodfellow PJ. Penetrance and expressivity of MSH6 germline mutations in seven kindreds not ascertained by family history. Am J Hum Genet 2004; 74: 1262-1269.

18. Broaddus RR, Lynch PM, Lu KH, Luthra R, Michelson SJ. Unusual tumors associated with the hereditary nonpolyposis colorectal cancer syndrome. Mod Pathol 2004; 17: 981-989.

19. Niessen RC, Berends MJ, Wu Y, Sijmons RH, Hollema H, Ligtenberg $\mathrm{MJ}$, de Walle HE, de Vries EG, Karrenbeld A, Buys $\mathrm{CH}$, van der Zee AG, Hofstra RM, Kleibeuker JH. Identification of mismatch repair gene mutations in young patients with colorectal cancer and in patients with multiple tumours associated with hereditary nonpolyposis colorectal cancer. Gut 2006; 55: 1781-1788.

20. Agostini M, Tibiletti MG, Lucci-Cordisco E, Chiaravalli A, Morreau H, Furlan D, Boccuto L, Pucciarelli S, Capella C, Boiocchi M, Viel A. Two PMS2 mutations in a Turcot syndrome family with small bowel cancers. Am J Gastroenterol 2005; 100: 1886-1891.

21. Auclair J, Leroux D, Desseigne F, Lasset C, Saurin JC, Joly MO, Pinson S, Xu XL, Montmain G, Ruano E, Navarro C, Puisieux A, Wang Q. Novel biallelic mutations in MSH6 and PMS2 genes: gene conversion as a likely cause of PMS2 gene inactivation. Hum Mutat 2007; 28: 1084-1090.

22. Bougeard G, Charbonnier F, Moerman A, Martin C, Ruchoux $M M$, Drouot N, Frébourg T. Early onset brain tumor and lymphoma in MSH2-deficient children. Am J Hum Genet 2003; 72: $213-216$.

23. De Rosa M, Fasano C, Panariello L, Scarano MI, Belli G, lannelli A, Ciciliano F, Izzo P. Evidence for a recessive inheritance of Turcot's syndrome caused by compound heterozygous mutations within the PMS2 gene. Oncogene 2000; 19: 1719-1723.
24. De Vos M, Hayward BE, Picton S, Sheridan E, Bonthron DT. Novel PMS2 pseudogenes can conceal recessive mutations causing a distinctive childhood cancer syndrome. Am J Hum Genet 2004; 74: 954-964.

25. De Vos M, Hayward BE, Charlton R, Taylor GR, Glaser AW, Picton S, Cole TR, Maher ER, McKeown CM, Mann JR, Yates $J R$, Baralle D, Rankin J, Bonthron DT, Sheridan E. PMS2 mutations in childhood cancer. J Natl Cancer Inst 2006; 98 : 358-361.

26. Gallinger S, Aronson M, Shayan K, Ratcliffe EM, Gerstle JT, Parkin PC, Rothenmund H, Croitoru M, Baumann E, Durie PR, Weksberg R, Pollett A, Riddell RH, Ngan BY, Cutz E, Lagarde $A E$, Chan HS. Gastrointestinal cancers and neurofibromatosis type 1 features in children with a germline homozygous MLH1 mutation. Gastroenterology 2004; 126: 576-585.

27. Hackman $P$, Tannergård $P$, Osei-Mensa S, Chen J, Kane MF, Kolodner R, Lambert B, Hellgren D, Lindblom A. A human compound heterozygote for two MLH1 missense mutations. Nat Genet 1997; 17: 135-136.

28. Hamilton SR, Liu B, Parsons RE, Papadopoulos N, Jen J, Powell SM, Krush AJ, Berk T, Cohen Z, Tetu B, et al. The molecular basis of Turcot's syndrome. N Engl J Med 1995; 332: 839-847.

29. Hegde MR, Chong B, Blazo ME, Chin LH, Ward PA, Chintagumpala MM, Kim JY, Plon SE, Richards CS. A homozygous mutation in MSH6 causes Turcot syndrome. Clin Cancer Res 2005; 11 : 4689-4693.

30. Krüger S, Kinzel M, Walldorf C, Gottschling S, Bier A, Tinschert S, von Stackelberg A, Henn W, Görgens H, Bove S, Kölble K, Büttner R, Schackert HK. Homozygous PMS2 germline mutations in two families with early-onset haematological malignancy, brain tumours, HNPCC-associated tumours, and signs of neurofibromatosis type 1. Eur J Hum Genet 2008; 16: 62-72.

31. Liu T, Tannergård $P$, Hackman $P$, Rubio $C$, Kressner U, Lindmark G, Hellgren D, Lambert B, Lindblom A. Missense mutations in hMLH1 associated with colorectal cancer. Hum Genet 1999; 105: 437-441.

32. Menko FH, Kaspers GL, Meijer GA, Claes K, van Hagen JM, Gille JJ. A homozygous MSH6 mutation in a child with cafe-aulait spots, oligodendroglioma and rectal cancer. Fam Cancer 2004; 3: 123-127.

33. Müller A, Schackert HK, Lange B, Rüschoff J, Füzesi L, Willert J, Burfeind P, Shah P, Becker H, Epplen JT, Stemmler S. A novel MSH2 germline mutation in homozygous state in two brothers with colorectal cancers diagnosed at the age of 11 and 12 years. Am J Med Genet A 2006; 140: 195-199.

34. Ostergaard JR, Sunde L, Okkels H. Neurofibromatosis von Recklinghausen type I phenotype and early onset of cancers in siblings compound heterozygous for mutations in MSH6. Am J Med Genet A 2005; 139: 96-105.

35. Plaschke J, Linnebacher M, Kloor M, Gebert J, Cremer FW, Tinschert S, Aust DE, von Knebel Doeberitz M, Schackert HK. Compound heterozygosity for two MSH6 mutations in a patient with early onset of HNPCC-associated cancers, but without hematological malignancy and brain tumor. Eur J Hum Genet 2006; 14: 561-566.

36. Poley JW, Wagner A, Hoogmans MM, Menko FH, Tops C, Kros $J M$, Reddingius RE, Meijers-Heijboer H, Kuipers EJ, Dinjens WN; Rotterdam Initiative on Gastrointestinal Hereditary Tumors. Biallelic germline mutations of mismatch-repair genes: a possible cause for multiple pediatric malignancies. Cancer 2007; 109: 2349-2356.

37. Rey JM, Noruzinia M, Brouillet JP, Sarda P, Maudelonde T, Pujol P. Six novel heterozygous MLH1, MSH2, and MSH6 and one homozygous MLHI germline mutations in hereditary 
nonpolyposis colorectal cancer. Cancer Genet Cytogenet 2004; 155: 149-151.

38. Ricciardone MD, Ozçelik T, Cevher B, Ozdag H, Tuncer M, Gürgey A, Uzunalimoglu O, Cetinkaya H, Tanyeli A, Erken E, Oztürk M. Human MLH1 deficiency predisposes to hematological malignancy and neurofibromatosis type 1. Cancer Res 1999; 59: 290-293.

39. Scott RH, Mansour S, Pritchard-Jones K, Kumar D, MacSweeney F, Rahman N. Medulloblastoma, acute myelocytic leukemia and colonic carcinomas in a child with biallelic MSH6 mutations. Nat Clin Pract Oncol 2007; 4: 130-134.

40. Scott RH, Homfray T, Huxter NL, Mitton SG, Nash R, Potter MN Lancaster D, Rahman N. Familial T-cell non-Hodgkin lymphoma caused by biallelic MSH2 mutations. J Med Genet 2007; 44: e83.

41. Trimbath JD, Petersen GM, Erdman SH, Ferre M, Luce MC, Giardiello FM. Cafe-au-lait spots and early onset colorectal neoplasia: a variant of HNPCC? Fam Cancer 2001; 1: 101-105.

42. Vilkki S, Tsao JL, Loukola A, Poyhonen M, Vierimaa O, Herva R, Aaltonen LA, Shibata D. Extensive somatic microsatellite mutations in normal human tissue. Cancer Res 2001; 61: 4541-4544.

43. Wang Q, Lasset C, Desseigne F, Frappaz D, Bergeron C, Navarro C, Ruano E, Puisieux A. Neurofibromatosis and early onset of cancers in hMLH1-deficient children. Cancer Res 1999; 59: 294-297.

44. Whiteside D, McLeod R, Graham G, Steckley JL, Booth K, Somerville MJ, Andrew SE. A homozygous germ-line mutation in the human $\mathrm{MSH} 2$ gene predisposes to hematological malignancy and multiple cafe-au-lait spots. Cancer Res 2002; 62: 359-362.

45. Pineda M, Castellsague E, Musulen E, Llort G, Frebourg T, BaertDesurmont S, Gonzalez S, Capella G, Blanco I. Non-Hodgkin lymphoma related to hereditary nonpolyposis colorectal cancer in a patient with a novel heterozygous complex deletion in the MSH2 gene. Genes Chromosomes Cancer 2008; 47: 326-332.

46. den Bakker MA, Seynaeve C, Kliffen M, Dinjens WN. Microsatellite instability in a pleomorphic rhabdomyosarcoma in a patient with hereditary non-polyposis colorectal cancer. Histopathology 2003; 43: 297-299.

47. Banville N, Geraghty R, Fox E, Leahy DT, Green A, Keegan D, Geoghegan J, O'Donoghue D, Hyland J, Sheahan K. Medullary carcinoma of the pancreas in a man with hereditary nonpolyposis colorectal cancer due to a mutation of the MSH2 mismatch repair gene. Hum Pathol 2006; 37: 1498-1502.

48. Soravia C, van der Klift H, Bründler MA, Blouin JL, Wijnen J, Hutter P, Fodde R, Delozier-Blanchet C. Prostate cancer is part of the hereditary non-polyposis colorectal cancer (HNPCC) tumor spectrum. Am J Med Genet A 2003; 121: 159-162.

49. Hirata K, Kanemitsu S, Nakayama $\mathrm{Y}$, Nagata N, Itoh $\mathrm{H}$, Ohnishi $\mathrm{H}$, Ishikawa $\mathrm{H}$, Furukawa $\mathrm{Y}$; HNPCC registry and genetic testing project of the Japanese Society for Cancer of the Colon and Rectum (JSCCR). A novel germline mutation of MSH2 in a hereditary nonpolyposis colorectal cancer patient with liposarcoma. Am J Gastroenterol 2006; 101: 193-196.

50. Vernez M, Hutter P, Monnerat C, Halkic N, Gugerli O, Bouzourene $\mathrm{H}$. A case of Muir-Torre syndrome associated with mucinous hepatic cholangiocarcinoma and a novel germline mutation of the MSH2 gene. Fam Cancer 2007; 6: 141-145.

51. South SA, Hutton M, Farrell C, Mhawech-Fauceglia P, Rodabaugh $\mathrm{KJ}$. Uterine carcinosarcoma associated with hereditary nonpolyposis colorectal cancer. Obstet Gynecol 2007; 1 10: 543-545.

52. Boyd J, Rhei E, Federici MG, Borgen PI, Watson P, Franklin B, Karr B, Lynch J, Lemon SJ, Lynch HT. Male breast cancer in the hereditary nonpolyposis colorectal cancer syndrome. Breast Cancer Res Treat 1999; 53: 87-91. 